\title{
PENINGKATAN KINERJA GURU MELALUI PROGRAM AKREDITASI MADRASAH
}

\author{
1A. Khalakul khoir \\ ${ }_{1}^{1}$ Universitas Islam Negeri Mataram \\ Email: akhalakulkhairi@uinmataram.ac.id
}

\begin{abstract}
Abstrak: Penelitian ini mengkaji tentang "Peningkatan Kinerja Guru Melalui Program Akreditasi Madrasah pada MTs Darul Hikmah Darek Lombok Tengah". Penelitian ini dilaksanakan selama enam bulan, mulai dari bulan Mei sampai bulan Oktober 2018 dengan bentuk kegiatan melakukan penggalian data melalui observasi, wancara dan dokumentasi untuk menemukan dan mengumpulkan data-data yang riil tentang bagaimana program akreditasi meningkatkan kinerja guru.Isu yang hangat pada tempat penelitian ini adalah bahwa kinerja guru belum maksimal disebabkan oleh faktor-faktor tertentu, baik faktor internal guru maupun faktor eksternal. Faktor internal meliputi kualifikasi pendidikan dan motivasi intrinsik maipun inovasi guru yang perlu dikembangkan. Sedangkan faktor eksternal meliputi perlunya lembaga memberi perhatian khusus pada para guru dan mengupayakan kerjasama dengan lembaga-lembaga lain yang dapat mendukung terlaksananya program-program pendidikan pada MTs Darul Hikmah secara optimal.Instrumen yang digunakan dalam mengumpulkan dan menganalisis data adalah observasi, dokumentasi dan wawancara. Data yang diperoleh diklasifikasi dan diverifikasi, sehingga terkumpul data yang diharapkan. Setelah data terkumpul melalui beberapa instrumen, peneliti melakukan triangulasi untuk memastikan bahwa data-data yang diperoleh benar-benar tepat dan absah Hasil penelitian ini menunjukkan bahwa Upaya peningkatkan kinerja para pelaku pendidikan dilakukan melalui kreatifitas dan inovasi para pelaku pendidikan baik kepala sekolah, para guru maupun staf administrasi, disamping itu juga dilakukan melalui programprogram madrasah bekerjasama dengan kementerian Agama dan Pemda setempat. Adapun program-program madrasah dalam mengoptimalkan kualitas tentu dengan menyiapkan berbagai sarana dan prasarana lembaga dan scara kontinyu melakukan pembinaan-pembinaan bagi sluruh komponen madrasah yang secara keseluruhan program madrasah mendapat apresiasi yang baik dari pihak yayasan maupun dari kalangan masyarakat dan pemerintah.
\end{abstract}

Kata Kunci: kinerja guru, akreditasi madrasah

Title: The Improvement of Teacher's Performance through the Islamic School (Madrasah) Accreditation Program

Author: A. Khalakul Khoir

Abstract: This research examines the Improvement of Teacher's Performance through the Islamic school (madrasah) Accreditation Program. This research is a qualitative research by carrying out the collection of the data through observation, interview and documentation to find and collect the real data about how accreditation programs can improve teacher's performance. The instruments used in collecting and analyzing data were observation, documentation and interviews. The data obtained were classified and verified, so that the expected data were collected. After the data were collected through several instruments, the researcher did triangulation to ensure that the data obtained were truly accurate and valid. The results of this research showed that the efforts of performance improvement of the education perpetrators are carried out through the creativity and innovation of education perpetrators both principal, teachers and administrative staff, besides that it is also carried out through Islamic school (madrasah) programs in collaboration with the Ministry of Religion and the local government. In optimizing the quality, Islamic school (madrasah) prepares various facilities and infrastructures of institution, it continuously carries out the coaching for all components of the Islamic school (madrasah) and overall Islamic school (madrasah) programs receive good appreciation from the foundation, the community and government.

Keywords: Teacher performance, Madrasah accreditation 


\section{PENDAHULUAN}

Akreditasi sekolah/madrasah adalah sebuah proses penilaian secara komprehensif terhadap kelayakan satuan lembaga atau program pendidikan, yang hasilnya diwujudkan dalam bentuk sertifikat pengakuan dan peringkat kelayakan yang dikeluarkan oleh suatu lembaga yang mandiri dan profesional.Kegiatan penilaian kelayakan dan kinerja suatu sekolah berdasarkan kriteria (standar) yang telah ditetapkan dan dilakukan oleh Badan Akreditasi Sekolah Nasional (BASNAS) yang hasilnya diwujudkan dalam bentuk pengakuan peringkat kelayakan sebagaimana diatur dalam Keputusan Menteri Pendidikan Nasional Nomor 087/U/2002.

Berdasakan hasil observasi pada MTs Darul Hikmah yang berada dibawah Yayasan Darul Hikmah, bahwa MTs ini belum terakreditasi, sehingga peneliti belum mengetahui kondisi riil mengenai kualitas dan kuantitas lembaga ini ${ }^{1}$, oleh karenanya, madrasah ini sebagai salah satu bagian dari sistem pendidikan nasional dituntut untuk selalu berupaya meningkatkan kualitas dalam penyelenggaraan pendidikan. Salah satu upaya untuk meningkatkan kualitas penyelenggaran pendidikan sebagaimana dimaksud di atas adalah dengan meningkatkan kinerja guru, sehingga dapat menghasilkan lulusan yang berkualitas, mampu bersaing serta mampu menghadapi tantangan zaman, dan peningkatan kinerja guru inilah yang akan menjadi bahan kajian dalam penelitian ini, dengan demikian peneliti akan mengupas secara detail urgensi akreditasi dalam mengoptimalkan kinerja guru di MTs Darul Hikmah.

Dalam buku Pedoman Akreditasi Madrasah Departemen Agama Republik Indonesi ${ }^{2}$, akreditasi secara terminologi didefinisikan sebagai suatu proses penilaian kualitas dengan menggunakan kriteria baku mutu yang ditetapkan dan bersifat terbuka. Dalam konteks akreditasi madrasah dapat diberikan pengertian sebagai suatu proses penulaian kualitas madrasah, baik madrsah negeri maupun swasta dengan menggunakan kriteria baku mutu yang ditetapkan pemerintah atau lembaga akreditasi. Hasil penilaian tersebut selanjutnya dijadikan dasar untuk memelihara dan meningkatkan kualitas penyelenggaraan dan pelayanan pendidikan lembaga yang bersangkutan.

Penyelenggaraan akreditasi sebagai salah satu kegiatan peningkatan mutu di bidang pendidikan, pada hakikatnya adalah agar penyelenggaraan pendidikan dapat mencapai standar kualitas yang ditetapkan dan pada gilirannya peserta didik dapat mencapai keberhasilan baik dalam penguasaan ilmu pengetahuan, keterampilan maupun dalam pembentukan kepribadian. ${ }^{3}$ Akreditasi adalah suatu kegiatan penilaian kelayakan suatu madrasah

${ }^{1}$ Observasi tanggal 15 September 2018

${ }^{2}$ Dalam Mulyono, Manajemen Administrasi dan Organisasi Pendidikan, (Jogjakarta: Ar-Ruzz Media, 2009), h. 279

${ }^{3}$ Mulyono, Manajemen Administrasi..., h. 266 
berdasarkan kriteria yang telah ditetapkan dan dilakukan oleh Badan Akreditasi Sekolah yang hasilnya akan diwujudkan dalam bentuk pengakuan peringkat kelayakan. ${ }^{4}$

\section{METODE PENELITIAN}

Adapun pendekatan penelitian yang digunakan untuk menjawab rumusan masalah di atas adalah pendekatan kualitatif dengan teknik deskriptif. Pendekatan kualitatif deskriptif yaitu suatu prosedur penelitian yang menghasilkan data deskriptif yang berupa data tertulis atau bisa dari orang-orang dan pelaku yang diamati. Pendekatan ini diarahkan kepada latar dan individu tersebut secara menyeluruh sebagai bagian dari suatu keutuhan. ${ }^{5}$

Tujuan menggunakan metode kualitatif deskriptif adalah: Memberikan bukti-bukti penelitian, Penelitian ini bertujuan untuk mengkaji secara mendalam tentang bagaimana program akreditasi meningkatkan kinerja guru. Isu yang hangat pada tempat penelitian ini adalah bahwa kinerja guru belum maksimal disebabkan oleh faktor-faktor tertentu, baik faktor internal guru maupun faktor eksternal.

Penelitian ini dilaksanakan selama enam bulan, mulai dari bulan Mei sampai bulan Oktober 2018 dengan bentuk kegiatan melakukan penggalian data melalui observasi, wancara dan dokumentasi untuk menemukan dan mengumpulkan data-data yang riil .

\section{HASIL PENELITIAN DAN PEMBAHASAN}

Di dalam proses akreditasi dievaluasi dalam kaitannya dengan arah dan tujuannya, serta didasarkan pada keseluruhan kondisi madrasah sebagai sebuah institusi belajar. Walaupun beragam perbedaan terjadi antar madrasah, tetapi madrasah dievaluasi berdasarkan standar tertentu. Standar diharapkan dapat mendorong dan menciptakan suasana kondusif bagi pertumbuhan dan memberikan rangsangan untuk terus berusaha mencapai mutu yang diharapkan.

\section{Fungsi Akreditasi Madrasah}

Departemen Agama dalam pedoman Akreditasi Madrasah ${ }^{6}$ menyebutkan bahwa akreditasi Madrasah memiliki beberapa fungsi sebagai berikut :

1) Perlindungan Masyarakat (Quality Assurance)

Maksudnya agar masyarakat memperoleh jaminan tentang kualitas pendidikan madrasah yang akan dipilihnya sehingga terhindar dari adanya praktik yang tidak bertanggung jawab.

2) Pengendalian Mutu (Quality Control)

${ }^{4}$ Himpunan Keputusan menteri pendidikan Nasional RI , (Jakarta : Sinar Grafika, 2008), h. 118

5 Bogdan dan Taylor, Kualitatif dan Dasar-Dasar Penelitian, (Surabaya: Usaha Nasional, 1993), h. 3

${ }^{6}$ Dalam Mulyono, Manajemen.. h. 279 
Maksudnya agar madrasah mengetahui akan kekuatan dan kelemahan yang dimilikinya sehingga dapat menyusun perencanaan pengembangan secara berkesinambungan.

3) Pengembangan Mutu (Quality Improvement)

Maksudnya agar madrasah merasa terdorong dan tertantang untuk selalu mengembangkan daan mempertahankan kualitas serta berupaya menyempurnakan dari berbagai kekurangan.

\section{Konsep Kinerja Guru}

Pada era sekarang dengan pertumbuhan informasi yang cepat terkadang tidak dapat dikendalikan untuk meraih keberhasilan lembaga pendidikan. kemampuan untuk mengelola informasi untuk pengambilan keputusan yang membawa keberhasilan organisasi adalah sangat penting. Kata yang penting dalam hal ini menurut Sulisworo ${ }^{7}$ adalah performansi. Performansi atau kinerja merupakan kata yang mempunyai makna penting bagi pengelolaan pendidikan dewasa ini.

Kinerja merupakan sesuatu yang sangat dibutuhkan dan bisa bermacammacam, berkembang dan berubah bahkan seringkali tidak disadari oleh pelakunya. Seseorang bekerja karena ada sesuatu yang hendak dicapainya dan orang berharap bahwa aktivitas kerja yang dilakukannya akan membawa kepada suatu keadaan yang lebih memuaskan daripada keadaan sebelumnya. ${ }^{8}$

Ada tiga hal yang yang mempengaruhi kinerja seseorang, yaitu:

1) Kebutuhan-kebutuhan (needs), adalah sesuatu yang harus dimiliki seseorang agar mampu bertahan hidup, sesuatu yang tanpa keberadaannya kita tidak mungkin hidup. Kebutuhankebutuhan dibagi ke dalam tiga level dengan mengadopsi hierarki kebutuhan dari Maslow yaitu : kebutuhan fisik, kebutuhan emosional, kebutuhan intelektual, kebutuhan altruistik atau spiritual. Pemenuhan atas tiap level kebutuhan ini adalah dasar yang harus dimiliki oleh seseorang untuk sampai pada tingkat aktualisasi diri sebagai tingkat yang paling tinggi.

2) Keinginan (wants), adalah berbeda dengan kebutuhan. Kebutuhan jelas diperlukan untuk kehidupan, contoh sepiring nasi, segelas air, dan sebagainya adalah sesuatu yang jelas harus tersedia agar kita dapat bertahan hidup. Keinginan adalah segala dalam diri seseorang yang mendorongnya untuk memilih dalam memenuhi kebutuhannya, tetapi keinginan ini tidak selalu dapat mengarahkan pada pilihan yang tepat. Seseorang dapat memilih benda, pergaulan atau kegiatan yang memang dibutuhkannya, oleh karena itu

\footnotetext{
${ }^{7}$ Dwi Sulisworo, manajemen dan Evaluasi Kinerja Lembaga Pendidikan dengan Balanced Score Card, (Semarang: PT. Sindur Press), h. 1

8 Anoragra. Psikologi Industri dan Sosial, (Jakarta: Dunia Pustaka Jaya, 1998),h. 55
} 
seseorang harus benar-benar merencanakan hidupnya agar tidak diperdaya oleh keinginan-keinginan nya sendiri yang kadang-kadang tidak seseuai dengan kebutuhannya.

3) Nilai-nilai (values), adalah sesuatu dalam diri seseorang yang mempengaruhi bentuk kebutuhan dan keinginan individu. Dengan kata lain, apa yang dibutuhkan dan diinginkan akan menggambarkan nilai-nilai yaang dimiliki individu.

Pengukuran kinerja merupakan suatu alat manajemen yang digunakan untuk meningkatkan kualitas pengambilan keputusan dan akuntabilitas.

Pengukuran kinerja juga digunakan untuk menilai pencapaian tujuan dan sasaran (goal and objective). Elemen kunci dari sistem pengukuran kinerja terdiri atas: 1). Perencanaan dan penetapan tujuan, 2). Pengembangan ukuran yang relevan, 3). Pelaporan format atas hasil, dan 4). Penggunaan informasi .

Menurut Sulisworo9 dalam pengelolaan lembaga pendidikan, pengukuran kinerja haruslah fokus pada pembelajaran siswa. Untuk mencapai hal tersebut diperlukan sistem yang berbasis pada fakta yang komprehensif dan terintegrasi. Sistem ini mencakup data input, data lingkungan, data kinerja, data kompetisi, dan lainnya.

Pengukuran kinerja guru dalam sebuah oerganisasi/ madrasah haruslah fokus pada hasil-hasil kunci. Hasil-hasil tersebut dapat digunakan untuk menciptakan nilai bagi siswa dan untuk para stakeholder kunci. Dengan menciptakan nilai bagi siwa dan para stakeholder, lembaga pendidikan dapat berkontribusi pada peningkatan kinerja pendidikan keseluruhan dan juga loyalitas. Selain itu, pengukuran kinerja digunakan pula dalam pengambilan keputusan yang berbasis fakta untuk menentukan dan menyesuaikan arah madrasah dan sumber daya yang digunakan di ruang kelas dan semua proses penting yang diselenggarakan pleh madrasah.

\section{Penetapan Indikator Kinerja Guru}

Tugas guru yang sangat dominan dalam proses belajar mengajar menuntut adanya pengembangan kualitas kinerja guru. Guru yang profesional dan kompeten hendaknya tidaklah langsung didapat dari ijazah pendidikan guru, namun harus belajar terus dari pengalaman, pengetahuan dan keterampilan tersendiri, perbaikan mengajar dilakukan secara berkelanjutan. ${ }^{10}$

Oleh sebab itu, pengembangan guru tidak terbatas melalui pengalaman mengajar masing-masing, tapi dengan mengikuti berbagai aktivitas yang menunjang profesionalitasnya

${ }^{9}$ Dwi Sulisw oro, Manajemen dan Evaluasi Kinerja....., h.2

10 Mainudin, Pengembangan dan Pelaksanaan Kurikulum yang Menjamin Tercapainya Lulusan yang Kreatif dalam Konvensi Nasional,(Jakarta: Gramedia Wicaksana, 1994), h. 23 
sebagai seorang tenaga pendidik melalui kelompok kerja guru, penataran-penataran, seminarseminar maupun melalui studi lanjut ke perguruan tinggi.

Dalam proses aktivitasnya guru perlu diukur kinerjanya secara konperhensif untuk mendapatkan informasi yang valid mengenai keberhasilan atau kegagalannya. Hal demikian dilakukan guna mengetahui tingkat ketercapaian indikator kinerja guru yang telah ditetapkan, terutama yang menyangkut ketercapaian sasaran pengajaran.

Ketercapaian indikator kinerja merupakan proses identifikasi dan klasifikasi indikator kinerja melalui sistem pemgumpulan dan pengolahan data atau informasi untuk menentukan pencapaian tingkatan kinerja kegiatan atau program. Penetapan indikator kinerja tersebut didasarkan pada kelompok menurut masukan (input), keluaran (output), hasil (outcome), manfaat (benefit) dan dampak (infact, serta indikator proses jika diperlukan untuk menunjukkan proses manajemen kegiatan yang telah terjadi.

Dengan demikian indikator tersebut dapat digunakan untuk melakukan evaluasi baik dalam tahap perencanaan maupun sampai selesainya program tersebut dilakukan. Ukuran kinerja menurut Sulisworo ${ }^{11}$ dapat dikelompokkan dalam salah satu dari enam kategori berikut :

a. Efektivitas

Efektivitas akan menjawab apakah lembaga pendidikan (dalam hal ini guru) telah menyelenggarakan sesuatu yang benar (doing the right things).

b. Efisiensi

Efisiensi memberikan jawaban bahwa lembaga pendidikan telah dijalankan dengan benar (doing things right).

c. Kualitas

Derajat dimana layanan akademik telah memenuhi persyaratan dan harapan peserta didik maupun pengguna lulusan.

d. Waktu

Ukuran dimana satuan aktivitas dijalankan dengan benar pada waktu yang telah ditentukan. Kriteria ini pada umumnya berdasar pada persyaratan dari peserta didik dan pengguna lulusan.

e. Produktivitas

Nilai tambah yang dihasilkan dari proses akademik terhadap sumber daya yang digunakan.

f. Safety

Ukuran keseluruhan kesehatan organisasi dan lingkungan kerja bagi peseta didik dan staf lembaga pendidikan.

${ }^{11}$ Dwi Sulisworo, Manajemen dan Evaluasi Kinerja... h. 3 


\section{Motivasi Kinerja Guru}

Laju perkembangan suatu rumah tangga perusahaan dalam rangka pembangunan bangsa menurut Alma ${ }^{12}$ ditentukan oleh kemampuan investasi, mutu produksi, efisiensi dan efektivitas, mutu pelayanan, dan profesionalisme. Semua masalah di atas terfokus sentral pada sumber daya manusia yang dibentuk melaui jasa pendidikan. Mc. Lelland telah mengadakan studi panjang di Jepang dan beberapa negara lain, dan hasilnya menunjukkan bahwa kunci kemajuan suatu pembangunan ekonomi termasuk perusahaan adalah need for achievement, dorongan untuk berprestasi.

Sebagai contoh Jepang dan Korea, keberhasilan dalam pembangunan ekonominya terletak pada keuletan, kesungguhan, kecermatan, ketekunan, kemampuan dalam memahami persoalan dan dalam mencari pemecahan yang tepat terhadap permasalahan yang dihadapi. Semua sifat-sifat ini dapat terbentuk dalam proses pendidikan yang harus dilatih oleh guru setiap hari.

Melihat realita ini, maka guru di Indonesia harus merasa iri dengan keadaan dan kinerja guru yang mampu menghasilkan lulusan yang berdaya saing secara global. Untuk itu diperlukan sosok guru yang memiliki motivasi kerja yang baik; rajin bekerja untuk tanah air, sangat setia kepada atasannya, menghargai lembaga pendidikan tempat ia bekerja, dan tidak berpura-pura tapi betul-betul mengajar dari lubuk hati yang paling dalam.

Motivasi kerja adalah sesuatu yang menimbulkan semangat atau dorongan kerja atau dorongan yang sangat kuat dalam menentukan terwujudnya suatu perbuatan yang direncanakan. Dorongan itu dapat berupa imbalan atau adanya ancaman. Dorongan juga dapat terjadi sebagai bagian daari kesadaran jiwa yang diimbangi oleh harapan terhadap sesuatu yang akan dicapai. ${ }^{13}$

\section{Peningkatkan kinerjanya Guru dan pegawai pada MTs Darul Hikmah}

Kinerja merefleksikan kesuksesan suatu organisasi, maka dipandang penting untuk mengukur karakteristik tenaga kerjanya. Kinerja guru merupakan kulminasi dari tiga elemen yang saling berkaitan yakni keterampilan, upaya sifat keadaan dan kondisi eksternal. Tingkat keterampilan merupakan bahan mentah yang dibawa seseorang ke tempat kerja seperti pengalaman, kemampuan, kecakapan-kecakapan antar pribadi serta kecakapan tehknik. Upaya tersebut diungkap sebagai motivasi yang diperlihatkan karyawan untuk menyelesaikan tugas pekerjaannya. Sedangkan kondisi eksternal adalah tingkat sejauh mana kondisi eksternal mendukung produktivitas kerja.

${ }_{12}$ Buchari Alma, manajemen Corporate dan Strategi Pemasaran Jasa Pendidikan; Fokus Pada Mutu dan Layanan Prima,(bandung: Al-Fabeta, 2008), h. 18

${ }^{13}$ Hikmat, Manajemen Pendidikan, (Bandung : Pustaka Setia, 2009), h. 272 
Kinerja dapat dilihat dari beberapa kriteria: (1). Karakteristik individu, (2). Proses, (3). Hasil dan (4) Kombinasi antara karakter individu, proses dan hasil.

Kinerja seseorang dapat ditingkatkan bila ada kesesuaian antara pekerjaan dengan keahliannya, begitu pula halnya dengan penempatan guru pada bidang tugasnya. Menempatkan guru sesuai dengan keahliannya secara mutlak harus dilakukan. Bila guru diberikan tugas tidak sesuai dengan keahliannya akan berakibat menurunnya cara kerja dan hasil pekerjaan mereka, juga akan menimbulkan rasa tidak puas pada diri mereka. Rasa kecewa akan menghambat perkembangan moral kerja guru. Moral kerja positifialah suasana bekerja yang gembira, bekerja bukan dirasakan sebagai sesuatu yang dipaksakan melainkan sebagai sesuatu yang menyenangkan. Moral kerja yang positif adalah mampu mencintai tugas sebagai suatu yang memiliki nilai keindahan di dalamnya. Jadi kinerja dapat ditingkatkan dengan cara memberikan pekerjaan seseorang sesuai dengan bidang kemampuannya. Kemampuan bersama-sama dengan bakat merupakan salah satu faktor yang menentukan prestasi individu, sedangkan prestasi ditentukan oleh banyak faktor diantaranya kecerdasan.

Kinerja dipengaruhi juga oleh kepuasan kerja yaitu perasaan individu terhadap pekerjaan yang memberikan kepuasan bathin kepada seseorang sehingga pekerjaan itu disenangi dan digeluti dengan baik. Untuk mengetahui keberhasilan kinerja perlu dilakukan evaluasi atau penilaian kinerja dengan berpedoman pada parameter dan indikator yang ditetapkan yang diukur secara efektif dan efisien seperti produktivitasnya, efektivitas menggunakan waktu, dana yang dipakai serta bahan yang tidak terpakai. Sedangkan evaluasi kerja melalui perilaku dilakukan dengan cara membandingkan dan mengukur perilaku seseorang dengan teman sekerja atau mengamati tindakan seseorang dalam menjalankan perintah atau tugas yang diberikan, cara mengkomunikasikan tugas dan pekerjaan dengan orang lain. Dalam melakukan evaluasi kinerja seseorang dapat dilakukan dengan menggunakan kriteria yaitu: dengan hasil tugas.

Hasil tugas, evaluasi hasil tugas adalah mengevaluasi hasil pelaksanaan kerja individu dengan beberapa kriteria (indikator) yang dapat diukur. Evaluasi perilaku dapat dilakukan dengan cara membandingkan perilakunya dengan rekan kerja yang lain dan evaluasi ciri individu adalah mengamati karaktistik individu dalam berprilaku maupun berkerja, cara berkomunikasi dengan orang lain.

Dari uraian diatas beberapa indikator kinerja guru antara lain:

a. Kemampuan membuat perencanaan dan persiapan mengajar.

Perencanaan mengajar yang disiapkan oleh guru pada MTs Darul Hikmah berdasar hasil penelitian meliputi RPP, media, buku paket, dan alat bantu pembelajaran yang diharapkan dapat menunjang pencapaian tujuan pembelajaran.

b. Penguasaan materi yang akan diajarkan kepada siswa 
Guru tidak hanya bertindak sebagai pengajar, namun lebih dari itu ia merupakan penanggung jawab perkembangan anak dalam masa-masa kehidupan mereka di sekolah. Pada MTs Darul Hikmah, guru disamping dituntut menguasai materi pelajaran yang akan diajarkan kepada siswa, para guru juga dituntut memiliki kematangan intelektual, kedewasaan dan wawasan berfikir yang diharapkan mampu membentuk kepribadian siswa menjadi pribadi yang dewasa, yang mampu bertanggung jawab, baik kepada dirinya sendiri, keluarga, masyarakat dan tanggung jawab kepada Allah SWT.

c. Penguasaan metode dan strategi mengajar

Salah satu kunci keberhasilan guru dalam mengajar dan menanamkan nilai-nilai kepribadian kepada siswa adalah guru menguasai metode yang akan digunakan dalam proses belajar mengajar. Guru yang menggunakan metode yang bervariasi pada umumnya lebih dominan menjadikan siswa termotivasi dalam belajar, sebab metode yang monoton cenderung menjadikan siswa menjadi pasif dan kreatif. Oleh karenanya guru dituntut menguasai metode dan strategi pembelajaran, sehingga perencanaan, proses dan hasil belajar siswa dapat tercapai secara optimal. Demikian halnya dengan para guru di MTs Darul Hikmah, juga dituntut menguasai berbagai metode dan strategi pembelajaran dalam melaksanakan pembelajaran di sekolah. Hal ini dimaksudkan disamping agar proses belajar mengajar berjalan dengan lebih maksimal, juga diharapkan para siswa diberi pengalaman mengenai bagaimana menerapkan metode dan strategi yang bervariasi, sehingga secara tidak langsung pada siswa juga tertanam kreatifitas mereka dalam belajar.

d. Pemberian tugas-tugas kepada siswa

Untuk melatih siswa dalam membaca dan menulis ilmiah, sekaligus untuk memperkaya cakrawala keilmuan mereka, pada guru dituntut memberikan tugas mandiri kepada siswa untuk dikerjakan secara individu maupun kelompok, apalagi saat ini bahwa kurikulum 2013 menuntut siswa memiliki kemandirian dalam memperlajari, mengkaji dan menguasai materi-materi (tema-tema) pelajaran di sekolah. Oleh karenanya pemberian tugas pada siswa di MTs Darul Hikmah juga diterapkan dalam rangka membiasakan siswa pendalaman materi-materi pelajaran yang telah diberikan oleh guru. Dalam pelaksanaannya para siswa diminta untuk mencari literatur-literatur yang sudah ditentukan oleh guru untuk menyelesaikan tugas-tugas mereka.

e. Kemampuan mengelola kelas

Mengelola kelas merupakan salah satu dari sembilan keterampilan dasar mengajar yang harus dimiliki oleh guru. Pengelolaan kelas merupakan keterampilan yang wajib dimiliki oleh guru.

Sebuah proses belajar mengajar akan dapat menuai hasil optimal tidak hanya sekedar karena metode, strategi dan fasilitas yang memadai. Apabila seluruh fasilitas tersedia, namun kemampuan guru dalam mengelola kelas tidak ada (minim), maka sangat mungkin 
kelas yang bersangkutan tidak akan dapat mencapai tujuan secara optimal. Kondisi ini juga menjadi perhatian pada MTs Darul Hikmah, bahwa para guru, melalui pelatihan-pelatihan yang diikuti dan melalui diskusi internal para pelaksana pendidikan di MTs Darul Hikmah juga melakukan hal yang sama, dimana mereka dituntut dan dibiasakan untuk mengelola kelas dengan sebaik-baiknya, sehingga proses belajar mengajar dapat berjalan secara optimal.

f. Kemampuan melakukan penilaian dan evaluasi.

Keterampilan yang tidak kalah pentingnya yang harus dimiliki oleh guru adalah kemampuan melakukan evaluasi. Menurut waktunya, evaluasi dapat dilakukan melalui tiga tahap yakni penilaian di awal, penilaian pada proses dan penilaian di akhir pembelajaran.

Penilaian awal ini yang biasa kita kenal dengan istilah pre test, yakni penilaian yang dilakukan sebelum proses belajar mengajar dilakukan, tes ini dimaksudkan untuk mengetahui sampai dimana peahaman siswa terhadap peguasaan materi yang telah mereka pelajari pada pertemuan sebelumnya. Tes awal ini dimaksudkan agar dapat menentukan apakah guru dapat melanjutkn materi berikutnya ataukah akan mengulangi lagi materi yang sudah diajarkan pada pertemuan sebelumnya.

Penilaian berikutnya adalah penilaian proses. Penilaian proses ini dimaksudkan untuk memonitoring daya tangkap siswa selama mengikuti proses belajar mengajar di kelas. Tes ini biasanya dilakukan secara lisan atau dengan memberikan tugas kepada siswa untuk diselesaikan pada saat berlangsungnya proses belajar mengajar.

Adapun penilaian terakhir yang dilakukan adalah penilaian/evaluasi sumatif. Penilaian ini dimaksudkan untuk mengukur sejauhmana penguasaan siswa terhaap materi pelajaran yang telah ditempuh dalam satu jenjang waktu tertentu. Tes (evaluasi) sumatif ini dijadikan sebagai dasar/pijakan dalam mengambil keputusan apakah siswa tertentu berhak untuk naik pada kelas/jenjang tertentu atau tidak. Hal demikian juga yang dilaksanakan pada MTs Darul Hikmah sebagaimana lembaga-lembaga formal pada umumnya.

\section{Program-program madrasah dalam mengoptimalkan kualitas dan kuantitas madrasah}

Peningkatan kinerja guru pada MTs Darul Hikmah dilakukan melalui berbagai program diantaranya:

a. Pelatihan-pelatihan kependidikan yang menunjang potensi dan kapasitas tenaga pendidik Pelatihan kependidikan yang diikuti oleh para guru adalah pelatihan penerapan kurikulum 2013 yang dilaksanakan secara internal dengan narasumber tiga orang guru yang pernah mengikuti pelatihan ini yakni Bapak Naskur, Ibu Nurainah dan Ibu Masni. Para guru yang pernah mengikuti pelatihan K13 baik di dalam maupun luar daerah menjadi tutor bagi guru yang belum mengikuti kegiatan ini. Menurut kepala sekolah MTs Darul Hikmah, 
sampai saat ini seluruh guru di MTs Darul Hikmah telah mengikuti program pelatihan Kurikulum 2013, sehingga kemampuan para guru hampir rata-rata mampu menerapkan kurikulum ini. ${ }^{14}$

b. Diskusi guru bersama kepala sekolah, wakasek dan tenaga administrasi.

Sebagai upaya mengoptimalkan kinerja seluruh tenaga kependidikan di MTs Darul Hikmah, lembaga ini secara rutin mengadakan diskusi internal dikalangan pengelola madrasah dan para guru. Diskusi ini dilaksanakan setiap minggu pertama awal bulan dengan topik yang berbeda-beda sesuai dengan program, masalah dan progres kegiatan lembaga. Diskusi ini dilaksanakan dalam rangka memecahkan berbagai persoalan yang dihadapi oleh para pelaku pendidikan, baik kepala madrasah, wakil kepala madrasah, para guru maupun staf Tata Usaha.

\section{Faktor pendukung dan penghambat optimalnya kinerja guru pada MTs Darul Hikmah}

a. Faktor Pendukung

1) Tenaga pendidik (guru) yang memiliki kualifikasi Sarjana (S1)

2) Sarana dan prasarana yang memadai

3) Dukungan keluarga besar Yayasan Darul Hikmah

4) Dukungan dari masyarakat sekitar dan kalangan keluarga siswa

5) Dukungan pihak pemerintah dalam hal ini pemda dan kemenag

6) Keinginan kuat untuk memperoleh akreditasi $A$

b. Faktor Penghambat

1) Kegiatan-kegiatan pelatihan untuk peningkatan kapasitas masih sangat sedikit dilaksanakan oleh lembaga

2) Kerjasama dengan lembaga-lembaga selain kemenag dan Pemda masih belum banyak dilakukan

3) Motivasi para pelaksana pendidikan belum optimal

4) Para pelaksana pendidikan masih disibukkan dengan rutininas di luar tugas pokoknya sebagai guru.

Dari beberapa faktor penghambat ini, perlu segera diambil tindakan sebagai upaya progresif dan aktif, mulai dari pembenahan manajemen, administrasi, membangun kerja sama dengan lembaga-lembaga donor (founding), lembaga pendidikan dan pelatihan baik lembaga pemerintah maupun swasta dengan harapan kesejahteraan para pelaksana pendidikan lebih diperhatikan, karena hal ini sangat memberi pengaruh pada kualitas para pelaku pendidikan yang implikasinya adalah capaian akreditasi yang belum maksimal (mencapai akreditasi A).

\section{${ }^{14}$ Ibid}




\section{Urgensi akreditasi madrasah bagi peningkatan kinerja guru pada MTs Darul Hikmah}

Akreditasi merupakan program pemerintah bagi semua lembaga pendidikan dalam rangka menjamin dan menjaga kualitas pendidikan, baik dari sisi manajemen, proses, output maupun outcome yang diharapkan mampu berkompetisi dalam lingkup regional, nasional dan internasional, sehingga dunia pendidikan di Indonesia mampu menempati posisi yang tidak kalah kualitasnya dengan lembaga pendidikan di negara lain.

Berdasarkan Keputusan Menteri pendidikan Nasional Nomor 087/U/2002, akreditasi sekolah mempunyai tujuan, yaitu: (1) memperolah gambaran kinerja sekolah sebagai alat pembinaan, pengembangan, dan peningkatan mutu; (2) menentukan tingkat kelayakan suatu sekolah dalam penyelenggaraan pelayanan pendidikan.

a. Tujuan Akreditasi Sekolah/Madrasah

Akreditasi sekolah/madrasah bertujuan untuk :

1) Memberikan informasi tentang kelayakan sekolah/madrasah atau program yang dilaksanakannya berdasarkan Standar Nasional Pendidikan.

2) Memberikan pengakuan peringkat kelayakan.

3) Memberikan rekomendasi tentang penjaminan mutu pendidikan kepada program dan atau satuan pendidikan yang diakreditasi dan pihak terkait.

Bagi para guru, hasil akreditasi sekolah/madrasah merupakan dorongan bagi guru untuk selalu meningkatkan diri dan bekerja keras untuk memberikan layanan yang terbaik bagi peserta didiknya. Secara moral, guru senang bekerja di sekolah/madrasah baik yang di akui sebagai sekolah/madrasah baik, oleh karena itu, guru selalu beruasaha untuk meningkatkan diri dan bekerja keras untuk mempertahankan dan meningkatkan mutu sekolah/madrasah.

Dalam rangka menempatkan program akreditasi sebagai bagian dari upaya sekolah/madrasah untuk meningkatkan mutunya secara berkelanjutan, maka sistem akreditasi dikembangkan dengan karakteristik yang memberikan:

a) Keseimbangan antara fokus penilaian kelayakan dan kinerja sekolah/madrasah;

b) Keseimbangan antara penilaian internal melalui evaluasi diri oleh sekolah/madrasah dan evaluasi eksternal oleh asesor;

Keseimbangan hasil akreditasi antara pemeringkatan status sekolah/madrasah dan umpan balik untuk peningkatan mutu sekolah/madrasah;

b. Fungsi Akreditasi Sekolah/Madrasah

Dengan menggunakan instrumen akreditasi yang komprehensif, hasil akreditasi diharapkan dapat memetakan secara utuh profil sekolah/madrasah. Proses akreditasi sekolah/madrasah berfungsi untuk: 
1) Pengetahuan, yaitu sebagai informasi bagi semua pihak tentang kelayakan sekolah/madrasah dilihat dari berbagai unsur terkait yang mengacu pada standar minimal beserta indikator-indikator.

2) Akuntabilitas, yaitu sebagai bentuk pertanggung jawaban sekolah/madrasah kepada publik, apakah layanan yang dilakukan dan diberikan oleh sekolah/madrasah telah memenuhi harapan atau keinginan masyarakat.

3) Pembinaan dan pengembangan, yaitu sebagai dasar bagi sekolah/madrasah, pemerintah, dan masyarakat dalam upaya peningkatan atau pengembangan mutu sekolah/madrasah.

c. Komponen Akreditasi Sekolah/Madrasah

1) Kurikulum dan Proses Pembelajaran

2) Administrasi dan Manajemen Sekolah/Madrasah

3) Oraganisasi dan Kelembagaan Sekolah/ Madrasah

Standar organisasi dan kelembagaan mencakup dua hal utama, yaitu organisasi dan legalitas serta regulasi sekolah/madrasah.

a) Organisasi

b) Legalitas dan Regulasi Sekolah/Madrasah

c) Sarana dan Prasarana

d) Ketenagaan

\section{SIMPULAN}

Upaya peningkatkan kinerja para pelaku pendidikan dilakukan melalui kreatifitas dan inovasi para pelaku pendidikan baik kepala sekolah, para guru maupun staf administrasi, disamping itu juga dilakukan melalui program-program madrasah bekerjasama dengan kementerian Agama dan Pemda setempat.

Program-program madrasah dalam mengoptimalkan kualitas tentu dengan menyiapkan berbagai sarana dan prasarana lembaga dan scara kontinyu melakukan pembinaan-pembinaan bagi sluruh komponen madrasah yang secara keseluruhan program madrasah mendapat apresiasi yang baik dari pihak yayasan maupun dari kalangan masyarakat dan pemerintah.

Dengan demikian urgensi akreditasi madrasah bagi peningkatan kinerja guru pada MTs Darul Hikmah cukup memberi warna dengan melengkapi standar-standar yang dapat menjadikan madrasah sebagai lembaga yang layak mendapat penghargaan melalui akreditasi

Dalam rangka mencapai akreditasi yang optimal, lembaga dituntut untuk mengoptimalkan berbagai komponen madrasah, sehingga kinerja guru dapat terlaksana secara optimal. Untuk mencapai kinerja optimal tersebut dibutuhkan managemen yang tepat, sehingga seluruh komponen dapat mencapai tujuan bersama yang diharapkan. 


\section{DAFTAR PUSTAKA}

Abdul Rachman Shaleh, Pendidikan Agama dan Pembangunan watak Bangsa. Jakarta: Grafindo Persada Anoraga. 1998, Psikologi Industri dan Sosial, Jakarta: Dunia Pustaka Jaya, 2005.

Buchari Alma, Manajemen Corporate dan Strategi Pemasaran Jasa Pendidikan; Fokus Pada Mutu dan Layanan Prima, Bandung: Al-Fabeta, 2008.

Departemen pendidikan Nasional, Manajemen peningkatan Mutu Berbasis Madrasah, Jakarta:

Direktorat Jenderal Pendidikan dasar dan Menengah, 2002.

Dinas pendidikan dan Kebudayaan, Akreditasi Madrasah dan Pembelajaran Tematik,(Semaramg: Grafindo Persada, 2005.

Hamzah B. Uno., Profesi Kependidikan; Problema, Solusi, dan Reformasi Pendidikan di Indonesia, Jakarta: Bumi Aksara, 2007.

Hikmat. Manajemen Pendidikan, Bandung : Pustaka Setia, 2003.

Mulyono, Manajemen Administrasi dan Organisasi Pendidikan, Jogjakarta: Ar-Ruzz Media. Abdul Rachman Shaleh, 2005.Pendidikan Agama dan Pembangunan watak Bangsa. Jakarta: Grafindo Persada Anoraga. 1998, Psikologi Industri dan Sosial, Jakarta: Dunia Pustaka Jaya, 2009.

Departemen Agama RI., Pedoman Akreditasi Madrasah. Jakarta: Direktorat Jenderal Kelembagaan Agama Islam Depag RI, 2005.

Departemen pendidikan Nasional, Manajemen peningkatan Mutu Berbasis Madrasah, Jakarta:

Direktorat Jenderal Pendidikan dasar dan Menengah, 2002.

Dinas pendidikan dan Kebudayaan , Akreditasi Madrasah dan Pembelajaran Tematik,(Semaramg: Grafindo Persada, 2005.

Dwi Sulisworo, Manajemen dan Evaluasi Kinerja Lembaga Pendidikan dengan Balanced Score Card, Semarang: PT. Sindur Press.

Hamzah B. Uno., Profesi Kependidikan; Problema, Solusi, dan Reformasi Pendidikan di Indonesia, Jakarta: Bumi Aksara, 2005.

Hikmat, Manajemen Pendidikan, Bandung : Pustaka Setia, 2009.

Himpunan Keputusan Menteri Pendidikan Nasional RI, Jakarta : Sinar Grafika, 2008.

Mainudin, Pengembangan dan Pelaksanaan Kurikulum yang Menjamin Tercapainya Lulusan yang Kreatif dalam Konvensi Nasional, Jakarta: Gramedia Wicaksana, 1994.

Mulyono. Manajemen Administrasi dan Organisasi Pendidikan, Jogjakarta: Ar-Ruzz Media, 2009. 